engineer with Siemens Brothers, and in 1905 went to the National Physical Laboratory and there became head of the Metrology Department. In 1910 he returned to Dublin as professor of engineering in the Royal College of Science for Ireland. In 1914 he became Dean of the College. During the Great War years his department was organized most successfully for the manufacture of munitions. In 1922 he received the degree of doctor of science of the University of Dublin. From 1918 until 1921 he was secretary to the Water Power Resources of Ireland Sub-Committee and took an active part in collaboration with Sir John P. Griffith, past president of the Institution of Civil Engineers, in the preparation of a scheme for the development of the water-power of the River Liffey. This scheme, though put on one side while the power resources of the Shannon were being developed, is now beginning to take practical shape under the rgis of the Electricity Supply Board.

In 1922 Jeffcott left Dublin for London on his appointment as secretary to the Institution of Civil Engineers, which position he filled until his death. His charming manner endeared him alike to his staff and the members of the Institution. $\mathrm{He}$ was very approachable and welcomed members who called on him, especially those home from abroad. His business ability and tact combined to bring to a successful conclusion many important negotiations with Government departments and public authorities. The recent reorganization of the Institution's activities brought much work to Dr. Jeffeott which the state of his health made very onerous. His early death, on June 29 at the age of sixty years, will prove a severe loss to the Institution and an irreparable one to those who had the good fortune to be his friends.

Though of exceptionally fine physique-Jeffeott was well over six feet in height and broad in proportion-he never took an active part in the athletic life of his college, though he thoroughly enjoyed a good game of tennis.

Jeffcott achieved considerable success as an inventor, being best known in this connexion through the Jeffeott direct-reading tacheometer. He was the author of papers on the vibrations of loaded shafts published in the Proceedings of the Royal Society and Philosophical Magazine, and of papers on water resources and other engineering subjects.

\section{Miss Dorothy Sladden}

By the tragic death of Miss Sladden in consequence of a motor accident on Saturday, June 20, a severe blow was struck at the science of experimental zoology. Miss Sladden was one of those rare people on whom Nature has bestowed an inborn love of animals and a marvellous skill amounting to genius in keeping them in good health and in inducing them to breed. She had not had a university education, but she was taken to the Imperial College by her parents as an occasional student, because they saw no other outlet for her peculiar abilities which had manifested themselves since she was quite a young girl.
After passing through the regular undergraduate course, at my suggestion Miss Sladden took up the question of the heritability of acquired habit and carried out with indomitable perseverance a series of experiments on this subject which extended over five years. She showed that the stick-insect (Carausius morosus) which is a native of southern India but which has been imported into Great Britain and is readily obtainable from dealers, could be induced by a series of periods of semi-starvation to accept a food (ivy) which was at first repugnant to it, and that the offspring of such insects accepted ivy more readily than did their parents, so that after five or six generations, 100 per cent of the insects accepted ivy at the first opportunity. In this species, males occur only at long intervals and the ordinary female is parthenogenetic, so that the complications involved in crossing different stocks are completely avoided. Two of her papers on this subject had already been published by the Royal Society, and a third in which she dealt successfully with objections which had been made to her first two papers, was nearly ready when a cruel fate snatched her away. Fortunately, this paper will be completed by our mutual friend, $\mathrm{Mr}$. H. R. Hewer, who assisted and advised her in statistical matters.

It may be justly said that Miss Sladden has demonstrated beyond reasonable doubt that functional inheritance is a reality; and this is the cardinal question in zoology, indeed in all biology. Once this conviction has gone home, the whole course of evolution becomes clear and doctrines like the recapitulatory theory of evolution which have been fiercely fought over, follow as a matter of course. That functional inheritance must be true is a conclusion which had already been accepted by leading palæontologists and systematists in the British and other great museums, but the distaste for it felt by a certain modern school of biologists is so great that they refused to accept any but direct experimental evidence in its favour. This has now been provided by Miss Sladden, and it is a feat which will make her name live in the annals of zoology.

\section{E. W. MacBride.}

WE regret to announce the following deaths :

Prof. E. B. Elliott, F.R.S., emeritus professor of pure mathematics in the University of Oxford, on July 21, aged eighty-six years.

Prof. W. T. Mather, professor of physics in the University of Texas, on June 14, aged seventy-two years.

Major Paul Murphy, formerly director of experiments, Chemical Warfare Station, Porton, on July 14.

Prof. S. C. B. Pennington, emeritus professor of agriculture in the University of Reading, on July 19, aged sixty-eight years.

Sir Charles E. Saunders, formerly Dominion cerealist, known for his work on the breeding of wheat in Canada, on July 25, aged seventy years.

Prof. Johannes Walther, emeritus professor of geology and palæontology in the University of Halle, on May 3, aged seventy-seven years. 